\section{John Stuart Mill's republican feminism ${ }^{1}$ \\ [O feminismo republicano de John Stuart Mill]}

\author{
Gustavo Hessmann Dalaqua \\ Doutorando em Filosofia pela Universidade de São Paulo, Brasil. \\ Mestre em Filosofia pela Universidade Federal do Paraná, Brasil. \\ E-mail: gustavodalaqua@yahoo.com.br
}

\begin{abstract}
This paper argues that John Stuart Mill's commitment to gender equality and acute understanding of women's subordination to male power led him to develop a conception of freedom that evokes republicanism. In order to substantiate the thesis that the concept of freedom put forth in The Subjection of Women steers a middle course between feminism and republicanism, four similarities between Mill's political theory and republican freedom are highlighted, among which are (i) the identification of freedom with the absence of arbitrary subjection and (ii) the idea that liberty can be exercised only among equals.

Keywords

John Stuart Mill. Feminism. Republicanism. Liberty. Equality.

\section{Resumo}

Este artigo sustenta que o compromisso com a igualdade de gênero e a percepção aguda da subordinação das mulheres ao patriarcado levaram John Stuart Mill a elaborar uma concepção de liberdade tributária do republicanismo. Para substanciar a tese de que o conceito de liberdade exposto em $A$ sujeição das mulheres trilharia uma via comum entre feminismo e republicanismo, destacam-se quatro semelhanças entre a teoria política de Mill e a liberdade republicana, dentre as quais constam (i) a identificação da liberdade com a ausência de sujeição arbitrária e (ii) a ideia de que a liberdade só pode ser exercitada entre iguais.

\section{Palavras-chave}

John Stuart Mill. Feminismo. Republicanismo. Liberdade. Igualdade.
\end{abstract}

\footnotetext{
1 This research received financial support from São Paulo Research Foundation, FAPESP grant \#2015/22251-0.
} 


\section{INTRODUCTION}

Under the influence of Isaiah Berlin (2000, p. 232), several scholars identify John Stuart Mill as one of the "fathers of liberalism" who should not be associated with the republican tradition. As one communitarian critic put it, Mill's philosophy represents the archetype of the liberal concept of freedom, the two main features of which would be "individualism" and the subordination of "community ... to the will of imperious individuals" (Gairdner, 2008, pp. 11, 14). According to William Gairdner, Mill subscribed to an individualistic conception of freedom that severed liberty from community and public life. Since it privatized freedom, Millian liberalism cannot be associated with a theory of liberty such as republicanism, which envisions freedom as a collective exercise of power among equals. ${ }^{2}$ In what follows, I take issue with such characterization and hold that Mill's political theory is based on a conception of freedom qua absence of arbitrary subjection that is akin to republicanism. The thesis this article seeks to put forward is that, by elaborating a conception of freedom as absence of arbitrary subjection in order to promote gender equality, Mill develops a feminist republican theory.

\section{THE SUBJECTION OF WOMEN AND THE POLITICAL RELEVANCE OF GENDER EQUALITY}

The Subjection of Women (SW) was for a long time one of the least studied of Mill's works. After publishing it, Mill's philosophical reputation was tarnished for having addressed what was then considered a "trivial" topic. Indeed, some nineteenth-century critics reputed Mill's book on the woman question to be "his greatest error as a scientific thinker" (Bain, 1882, p. 146). It was only in the 1960s that the philosophical value of SW

\footnotetext{
2 Kenneth Minogue (1988, p. 194) offers a typical statement of the opposition between "liberalism" and "republicanism" that several scholars suppose to exist. Leaving aside the possible merits that such dichotomy might entail, the truth is that, at least from a Millian perspective, the opposition between "republicanism" and "liberalism" is untenable. Therefore, one ought to recognize that, far from being opposed political theories, "liberalism" and "republicanism" are inextricably bound up with one another in the works of some modern philosophers (Dagger, 1997, ch. 1). "Freedom" and "liberty," as well as "classical" and "ancient," are employed interchangeably throughout the text. Unless otherwise noticed, all translations are mine.
} 
started being appreciated (Morales, 2005, pp. xiii-xiv). Since then, the recognition of the book's philosophical richness has only increased. Far from being a minor work, SW is a key text for understanding the articulation between two of the most important concerns of Mill's political philosophy, viz. liberty and equality (Rosen, 2013, pp. 245-6).

The connection between liberty and equality is one of the theses put forth in $S W$ that allows us to label Mill's feminism as republican. Mill can be classified as a feminist republican because his commitment to equality between the sexes and acute understanding of women's subordination to male power led him to identify freedom with the absence of arbitrary subjection. Although dozens of commentators have referred to Mill as either "feminist" or "republican," as far as our readings go, only one scholar has called him a feminist republican. In Women's Rights as Multicultural Claims, Monica Mookherjee (2009, p. 132) surmises that Mill should be associated with "republican feminism." This essay builds on Mookherjee's insight and seeks to substantiate her brief remark by dint of an analysis of the concept of liberty that undergirds Millian feminism.

In the beginning of SW, Mill expands the semantic horizon of the concept "despotism" and portrays the relations that take place between men and women in the socalled "private" realm as despotic. "Not a word can be said for despotism in the family which cannot be said for political despotism" (CW XXI, p. 286). ${ }^{3}$ Mill's use of the concept "despotism" in SW is at once classical and innovative (Urbinati, 2007, p. 67). It is classical because Mill associates it with the absolute subjection of one person to the arbitrary will of another - despotes was how the ancient Greeks designated the slave owner - and innovative because Mill uses it to condemn abusive power relations that the ancients deemed natural. By depicting the relations between husband and wife as despotic, Mill took to task the ancient view that relations practiced in the private realm of the house (oikos) should be insulated from politics. Accordingly, he urged politicians to create laws forbidding the subjection of women in the domestic sphere, thus anticipating the modern feminist motto that the private is political. "Mill, unlike most liberals, was willing to think the idea of equality and non-hierarchy straight into the bosom of the 'private sphere', to demolish the idea that this sphere should be immune from legal regulation" (Nussbaum,

\footnotetext{
3 Following common practice amongst Mill scholars, references to The Collected Works of John Stuart Mill are written as follows: CW XVIII, p. 266, for Collected Works, volume XVIII, page 266.
} 
2005, p. 108). ${ }^{4}$ The subjection of women in the private sphere is of public relevance because the existence of unequal power relations in the house undermines the viability of equality in the political realm.

In chapter four of SW, Mill contrasts the lifestyle of modern men with the ethics of chivalry and claims that Victorian men used to spend much more time at home with the family than previous generations. Hence, struggling against the existence of unequal relations in the house is imperative, for prolonged interaction with inequality in the "private" sphere hinders the capacity of individuals to treat others equally in the political realm. Put differently, "free government" cannot set roots in a society where family "despotism" is the norm (CW XXI, p. 292).

The comparisons between the political world and the domestic sphere are ubiquitous in SW. First, Mill affirms that the domestic sphere, like the political realm, is crossed by power relations and that, therefore, the division of "powers and responsibilities" it involves should be made consensually, not despotically (CW XXI, p. 291). Then, he puts forth the thesis that the "family, justly constituted," fulfills the same role "citizenship" does, for it also functions as "a school of society in equality [and] of the virtues of freedom" (CW XXI, p. 295). Next, he maintains that the "relation between husband and wife is very like that between lord and vassal" (CW XXI, p. 325). In the final chapter, he explains that the experience in the family can teach "the knowledge of life and faculty of government," which are both fundamental to public life (CW XXI, p. 339).

"The law of servitude in marriage is a monstrous contradiction to all the principles of the modern world, and to all the experience through which those principles have been slowly and painfully worked out" (CW XXI, p. 323). For Mill, "the equal freedom" citizens in more democratic societies enjoyed was not conquered easily ( $C W X X I, p .281)$. The levelling of inequalities among human beings was the product of collective struggles:

The capacity of cooperation for a common purpose, heretofore a monopolized instrument of power in the hands of the higher classes, is now a most formidable one in those of the lowest. Under these influences it is not surprising that society makes greater strides in ten years, towards the levelling of inequalities, than lately in a century, or formerly in three or four (CW XVIII, p. 51).

When unequal treatment of human beings is backed by law, those who are on the top of the hierarchy are usually unwilling to give up their privileges. More often than not,

\footnotetext{
${ }^{4}$ For an assessment of how Mill's feminism challenges the public vs. private dichotomy, see also Keith Burgess-Jackson (2005) and Martha Nussbaum (2010, p. 134).
} 
those privileged by non-egalitarian institutions consider the power to subjugate "inferior" individuals a natural trait of human existence. Thus, it was understandable that most Victorian men had "a real antipathy to the equal freedom of women" (CW XXI, p. 281). After all, "was there ever any domination which did not appear natural to those who possessed it?" (CW XXI, p. 269.) Mill's rhetorical question is part of a wider argumentative strategy that a reader fairly acquainted with his works can already discern at this juncture of the text. Whereas On Liberty sought to convince its readers that persecuting minorities was noxious to the majority, $S W$ aims to prove that the subjection of women is detrimental to men. $S W$ is a rhetorical text because its goal is to persuade the perpetrators of female subjection to change their attitudes and beliefs. Seeking to maximize the impact of his theoretical intervention, Mill delayed publication of $S W$ - originally written in 1861 - until the campaign for female suffrage, which he helped initiate, had created a more receptive audience (Collini, 1984, p. xii).

In order to convince men to support women's liberation, Mill devotes a large part of $S W$ to demonstrate that gender inequality is deleterious not only to women but also to men. Hence the aforementioned sentence that the subjection of women represented "a monstrous contradiction" to the principles of a free republic. The existence of despotism in the family sphere is monstrous because it "distorts" the nature and character of those involved in it (CW XXI, pp. 276, 305). What is more, gender inequality is worse to its perpetrators than to those who are oppressed by it:

And it is true that servitude ...., though corrupting to both, is less so to the slaves than to the slave-masters. It is wholesomer for the moral nature to be restrained, even by arbitrary power, than to be allowed to exercise arbitrary power without restraint (CW XXI, pp. 320-1).

This thesis, introduced in the end of chapter three, is further developed in the beginning of chapter four:

All the selfish propensities, the self-worship, the unjust self-preference, which exist among mankind, have their source and root in, and derive their principal nourishment from, the present constitution of the relation between men and women. Think what it is to a boy, to grow up to manhood in the belief that without any merit or any exertion of his own, though he may be the most frivolous and empty or the most ignorant and stolid of mankind, by the mere fact of being born a male he is by right the superior of all and every one of an entire half of the human race ... What must be the effect on his character, of this lesson? . . . The relation between husband and wife is very like that between lord and vassal, except that the wife is held to more unlimited obedience than the vassal was. However the vassal's character may have been affected, for better and for worse, by his 
subordination, who can help seeing that the lord's was affected greatly for the worse? (CW XXI, pp. 324-5.)

People tend to believe inequality is bad only for those who are materially disadvantaged because of it. Yet inequality is morally corrupting for both the oppressed and the oppressors, and can even be more corrupting to the latter than to the former. The thesis that social subjugation corrupts first and foremost its perpetrators was prominent in the abolitionist literature, which was very prolific in the nineteenth century. The memoirs of Frederick Douglass, an abolitionist who at the age of twenty escaped slavery and began a life as a free man in the north of the U.S., is a good case in point. In Narrative of the Life of Frederick Douglass (1845), the former slave offers a poignant account of how the practice of slavery corrupts the character of slave owners. In a letter sent to Harriet Taylor, Mill mentions Douglass' activism and praises the coalition between feminists and abolitionists in the U.S. (CW XIV, p. 49).

The convergence between feminists and abolitionists is not surprising once one realizes that both groups sought to advance the same cause: the equal liberty of all human beings, regardless of sex and race. Since Mill was a staunch supporter of this cause, it is comprehensible that feminism and abolitionism intersect in SW. The analogy between women's subjection and slavery comes up countless times throughout the book; "no slave is a slave to the same lengths, and in so full a sense of the word, as a wife is" (CW XXI, p. 284). 5

Mill casts women's situation in such negative terms because he believes the subjection of women "enslave[s] their minds," something that according to him did not happen with African slaves (CW XXI, p. 271). Women were taught to passively accept the curtailment of their freedom and to take pleasure in their subjection. Consequently, "the object of being attractive to men had ... [had] become the polar star of feminine education and formation of character" (CW XXI, p. 272). Men's despotism over women did not have to translate into actual physical repression, for in many cases women themselves

\footnotetext{
${ }^{5}$ At first glance, Mill's comparison may seem hyperbolic. One should bear in mind, however, that portraying women's subjection as a slave-like condition was not unusual among modern philosophers. See, for instance, Mary Wollstonecraft (2007), a representative of eighteenth-century English republicanism who also depicted the subjugated woman as a "slave." In the seventeenth and eighteenth centuries, the term "slavery" was utilized in a different sense than nowadays. "The word 'slavery' was then used in a much broader sense to describe any ostensibly intolerable situation of dependence. The connotations of the word were primarily political and social, and only in a secondary sense was it used to denote a legal regime of economic servitude" (Rosanvallon, 2011, p. 40). Algernon Sidney (1996 [1698], p. 17) epitomizes such use of the term when he states: "To depend upon the will of a man is slavery."
} 
consented to being subjugated. "Despotism [for Mill] designates power relations marked by the absence of autonomously reached consent, not by the absence of any kind of consent" (Urbinati, 2007, p. 85). The absence of resistance and the presence of consent are not enough to ascertain the existence of freedom. To determine whether freedom is present in politics or in the family, it is necessary to analyze the process of consent formation. Organized resistance against any kind of domination depends upon the availability of discourses and interpretative schemes that allow the dominated to frame their subjection as an actual obstacle to freedom. If the education given by society does not give tools for the subjugated to detect the curtailment of their freedom, resistance against despotism never comes about.

In the last pages of $S W$, Mill writes that one of the goals of his book was to shed light on "the difference . . . between a life of subjection to the will of others, and a life of rational freedom" (CW XXI, p. 336). This sentence merits attention, for it puts into question the interpretation of those who claim that Mill espoused the negative concept of liberty. ${ }^{6}$ As the next section highlights, SW develops a conception of liberty qua absence of arbitrary subjection that links Mill's political philosophy to the republican tradition (Skinner, 1998, pp. ix-x).

\section{MILL'S FEMINIST REPUBLICANISM}

"The republican tradition is unanimous in casting freedom as the opposite of slavery" (Pettit, 1997, p. 31). ${ }^{7}$ The antithesis between liberty and slavery, which is central to the arguments presented in $S W$, reveals that Millian freedom can be classified as republican:

The most striking feature of these [republican] definitions [of liberty] is that they owe their phraseology entirely to the analysis of freedom and slavery at the outset of the Digest of Roman law. There we are first informed that 'the fundamental division within the law of persons is that all men and women are either free or are slaves'. Next we are given a formal definition of slavery: 'slavery is an institution of the ius gentium by which someone is, contrary to nature, subjected to the dominion

\footnotetext{
${ }^{6}$ Berlin (2000, p. 198) was the one responsible for consolidating the interpretation that Mill was a proponent of negative liberty.

${ }^{7}$ My reading of the republican tradition follows the studies of neo-republican scholars such as Phillip Pettit, Quentin Skinner, and Jean-Fabien Spitz. Besides them, this section also examines the work of an ancient republican writer who influenced Mill's philosophy, namely, Sallust. Since the main purpose of the section is to spell out the republican traits of Mill's theory of liberty, the differences between Pettit, Skinner, and Spitz are not addressed here.
} 
of someone else'. This in turn is held to yield a definition of individual liberty. If everyone in a civil association is either bond or free, then a civis or free citizen must be someone who is not under the dominion of anyone else, but is sui iuris, capable of acting in their own right. It likewise follows that what it means for someone to lack the status of a free citizen must be for that person not be sui iuris but instead to be sub potestate, under the power or subject to the will of someone else (Skinner, 2002, pp. 248-9).

One of the most distinctive features of the republican concept of liberty is that, unlike Hobbesian freedom, republicans do not think the absence of interference is enough to ensure liberty (Hobbes, 2004, p. 171). As Skinner explains in the aforementioned passage, it is the absence of subjection to the discretionary will of someone else, not the absence of interference tout court, that indicates the presence of liberty.

In contemporary political philosophy, republicanism has been a subject of critical scrutiny for several years now. In order to specify the singularity of republican freedom, scholars oftentimes allude to the famous dichotomy between "negative liberty" and "positive liberty" postulated by Berlin (2000, pp. 201-2):

\begin{abstract}
Liberty in this [negative] sense is principally concerned with the area of control, not with its source. Just as a democracy may, in fact, deprive the individual citizen of a great many liberties which he might have in some other form of society, so it is perfectly conceivable that a liberal-minded despot would allow his subjects a large measure of personal freedom. . . Freedom in this sense is not, at any rate logically, connected with democracy or self-government. . . . [T] necessary connection between individual liberty and democratic rule. The answer to the question 'Who governs me?' is logically distinct from the question 'How far does government interfere with me?' It is in this difference that the great contrast between the two concepts of negative and positive liberty, in the end, consists.
\end{abstract}

In its negative sense, freedom is, if not opposed to, at least indifferent to politics. The greatest difference between negative and positive liberty is that the former is compatible with any kind of political regime, whereas the latter is not. According to Berlin's account, freedom is "positive" when associated with the presence of a certain arrangement of political power, viz. democracy. Negative liberty, in contrast, is concerned only with the absence of interference. Hence, not surprisingly, some scholars studying republicanism nowadays hold that, inasmuch as it associates freedom with the absence of domination, republican freedom is negative (Pettit, 1997, p. 27). ${ }^{8}$ Closer inspection, however, shows that the identification of republicanism with negative liberty should be taken cum grano salis, for the republican concept of freedom

\footnotetext{
8 Skinner (1998) prefers to use "dependence" instead of "domination." Pettit (2002, p. 341) claims that "dependence" and "domination" describe the same phenomenon, and argues that Skinner's different terminology does not amount to any significant divergence between them.
} 
is characterized by the presence of something, since not being dominated implies getting rid of the uncertainty and vulnerability of situations of dependence. In republican thought, freedom is assessed neither only on the basis of noninterference nor only on the basis of the extension of actions granted to individuals. Rather, [the assessment of freedom] also takes into account the degree of immunity against arbitrary interventions. So, republican freedom is wider than negative liberty, for it aims not only to protect individuals from interference, but also to ensure securities for such protection, thus emancipating individuals from the conditions of precarity that characterize subjection to a discretionary power (Barros, 2015, p. 28).

The absence of arbitrary subjection does not happen spontaneously and requires the presence of instruments that allow individuals to surveil, contest and punish the conduct of those with whom they interact in power relations. Besides the containment of arbitrary power, republicanism cannot do without the exercise of political power: "The republican regime does not only propose that power should be regulated by laws and performed ... . for the sake of the common good. It requires also that power be exercised somehow by the whole people" (Cardoso, 2004, pp. 46-7). One could surmise, therefore, that Berlin's opposition between negative and positive liberty does not do justice to the multifarious character of republican freedom. Likewise, Berlin's dichotomy cannot grasp the complexity of Millian liberty, which also posits that freedom requires both the containment and exercise of political power. ${ }^{9}$

Nevertheless, it may not be amiss to observe that in one of the first articles he published about liberty, Mill did espouse a negative conception of liberty:

Liberty, in its original sense, means freedom from restraint. In this sense, every law, and every rule of morals, is contrary to liberty. A despot, who is entirely emancipated from both, is the only person whose freedom of action is complete (CW I, p. 296).

The definition of liberty given above was written when Mill was sixteen and doubtless exemplifies the negative concept of liberty. Liberty means absence of restraint and, since the function of every law and rule is to restrain, free is he who can emancipate himself from the burden of all laws and rules. Mill's mention of the despot as a paramount example of a free man is significant, for it exposes the chasm that separates this early piece from Mill's mature thinking about liberty. As we will explain shortly, Mill affirms in SW that a despot can never be free, for being a master among servants deprives him from a basic condition of liberty.

\footnotetext{
${ }^{9}$ On the inability of Berlin's antithesis to grasp Mill's theory of liberty, see Robert Devigne (2006, ch. 7).
} 
In the last chapter of SW, Mill associates freedom with self-government, that is, with "the liberty of each to govern his conduct by his own feelings of duty, and by such laws and social restraints as his own conscience can subscribe to" (CW XXI, p. 336). Freedom is inextricably bound up with the practice of critique. If a citizen is to maintain her freedom, she must critically scrutinize the laws and social restraints that govern her conduct. By doing so, she takes part in politics and becomes an active citizen who, whenever a given policy is considered unjust to her, can assemble with others and pressure elected officials. As a supporter of a participatory republic, Mill thinks political participation should not be confined to the solitary act of voting and insists that those who are outside government institutions should also be political participants:

Reading newspapers, and perhaps writing to them, public meetings, and solicitations of different sorts addressed to the political authorities, are the extent of the participation of private citizens in general politics, during the interval between one parliamentary election and another. ... [l]t is impossible to exaggerate the importance of these various liberties, both as securities for freedom and as means of general cultivation (CW XIX, p. 535).

Mill thinks political participation wards off the specter of arbitrary subjection. Conversely, when people no longer engage in politics and cease to monitor and contest their representatives, they sooner or later see themselves hostages to an arbitrary government. In chapter two of Considerations on Representative Government, Mill explains he envisions political life "as conceived by the ancients . . [W]e ought not to forget, that there is an incessant and ever-flowing current of human affairs towards the worse, consisting of all the follies, all the vices, all the negligences . . . of mankind" (CW XIX, p. 388). Mill here alludes to the republican idea that corruption can never be held entirely in abeyance. In the absence of virtuous and active citizens, even the most perfectly designed political regime is doomed to decay. ${ }^{10}$

Like the majority of republican thinkers, Mill thinks despotism, arbitrary subjection, and tyranny - in short, the absence of freedom - cannot be identified with interference tout court. Ultimately, all time lived in the absence of warranties against arbitrary interference constitutes a time of non-freedom. From that perspective, a woman living under the dominion of a magnanimous husband or father who never interferes with her conduct remains unfree. Magnanimousness describes the kind behavior of someone who has the

10 For an analysis of Mill's conception of virtue and its affinity with the republican tradition, see Bernard Semmel (1984, p. 110). For an assessment of the issue of corruption in republican thought, see Newton Bignotto (2008). 
power to interfere with another's conduct in a whimsical manner, but who decides not to do it. The problem is that when the good will of the master subsides, magnanimousness tends to disappear. When a woman living under the shadow of arbitrary subjection comes to terms with her predicament, she starts policing her words and deeds in such a way as to avoid arousing the master's anger - which, her greatest efforts notwithstanding, remains a very imperfect way of dodging actual interference, for nothing guarantees the master will not suddenly become cranky and decide, without any reason, to oppress her.

No wonder then republicans of previous generations used to associate "effeminate" manners with arbitrary subjection and the self-policing lifestyle ensued from it. Indeed, Mill explains, such lifestyle was widespread among Victorian women - not due to a putative feminine nature, but because women were under arbitrary subjection:

When we put together three things - first, the natural attraction between opposite sexes; secondly, the wife's entire dependence on the husband, every privilege or pleasure she has being either his gift, or depending entirely on his will; and lastly, that the principal object of human pursuit, consideration, and all objects of social ambition, can in general be sought or obtained by her only through him, it would be a miracle if the object of being attractive to men had not become the polar star of feminine education and formation of character (CW XXI, p. 272).

Sycophancy, servility, and the duplicity that someone at pains to please a superior master at all costs is forced to cultivate were for ancient republicans the traits that made men living under arbitrary regimes "effeminate." In the case of Victorian women, the dependence over a man's will, together with a set of rules that made them revel in their subjection, created a vicious circle that led women to shape all their lives with the intention of pleasing their master. For republican thinkers, to live without freedom is to be dependent on the will of somebody; this applies even if you submit willingly. In fact, it applies particularly if you submit willingly, for doing so shows that even your emotions and desires were shaped in such a way as to make you accept the slavery you are in. What is cruel for Mill about women's subjection is that they are trained not only to live a life with no freedom, but to love it. Slavery reaches its peak when those living under arbitrary subjection do not even regard themselves as unfree anymore or when they cleave to their slavery willfully.

Arbitrary subjection deprives individuals of an essential component of Millian liberty: the full development of their intellectual faculties and talents. To be sure, the complaint that a life under arbitrary subjection robs human beings of the opportunity to develop their 
talents was not uncommon among classical republicans. In the beginning of Bellum Catilinae, Sallust (1931, pp. 13, 15), for instance, offers the following contrast between a free polity and a tyrannical regime:

They [sc. the Romans] had a constitution founded upon law, which . . . at first tended to preserve freedom and advance the state ... Now at that time every man began to lift his head higher and to have his talents more in readiness. For kings hold the good in greater suspicion than the wicked, and to them the merit of others is always fraught with danger; still the free state, once liberty was won, waxed incredibly strong and great in a remarkably short time, such was the thirst for glory that had filled men's mind. . . . [T] heir hardest struggle for glory was with one another; each man strove to be the first to strike down the foe, to scale a wall, to be seen of all while doing such deed. This they considered riches, this fair fame and high nobility.

Sallust's account shows that while arbitrary subjection makes men hide their talents so as not to arouse the master's suspicion, the liberty sponsored by the republic created a friendly environment for the development of citizens' potentialities. For Sallust as for other republicans, freedom should not be mistaken with the absence of interference tout court. Freedom, instead, requires the presence of egalitarian relations that allow individuals to face one another with their heads lifted, without having to act in a servile or duplicitous manner. Only in the presence of equals can citizens' freedom take place. Sallust's account, in sum, reveals that the republic constituted the reverse of a despotic regime: whilst the latter promoted sycophancy, suspicion, selfishness and the isolation of individuals, the former gave birth to a public space where freedom and equality before the law allowed citizens to express the unique talents that singularized them. Even though Mill does not cite Sallust when theorizing freedom as non-subjection, it is possible to conjecture that he was influenced by the Sallustian thesis according to which a free republic begets a friendly environment for the development of citizens' potentialities. For, according to the Autobiography, when Mill was young he studied with his father all books Sallust wrote (CW I, p. 14).

Be that as it may, what is undeniable is that one of republicanism's main tenets the idea that liberty implies the absence of arbitrary subjection - is part and parcel of Millian liberty. Accordingly, an authoritarian leader who manages to reduce criminality can never offer a good government:

Look at the government of Napoleon Bonaparte: if security from robbery and murderers constituted good government, there never was a better government than his. But security from robbers and murderers is a small part of good government and includes only that very subordinate department called police. Why 
do we call Bonaparte's government a bad one? Because if person and property were secure against individuals, they were not secure against the despot. $\mathrm{He}$ suppressed all robbers and murderers but himself (CW XXVI, p. 282).

A people living under arbitrary subjection is never safe, for their property over their estates and over themselves can always be usurped by their master. An authoritarian regime that promises safety in the place of political participation cannot honor its vow, because it leaves its subjects at the mercy of a discretionary power. "I would rather if I must choose, be habitually overtaxed, than live in constant fear that the whole of my property might be taken from me at a moment's warning by the fiat of a despot" (CW XXVI, p. 346). A lawful state is better than a despotic regime where citizens are never taxed; "a government of law is always preferable to a government of arbitrary will" (CW XXVI, p. 346). Mill wanted to eliminate one of the main features of arbitrariness, viz. unpredictability. "I can hardly imagine any laws so bad, to which I would not rather be subject than to the caprice of a man" (CW XXVI, p. 346). Echoing a common republican theme, Mill extols the Empire of the Law because, by precluding the despot's caprice to take over the power of the Law, it bestows predictability on citizens' life.

Mill was against arbitrary interference, not interference as such; "he did not think that constraints imposed by nonarbitrary laws were in themselves an offence against liberty" (Urbinati, 2002, p. 168). Whence it follows, according to Urbinati, that Millian liberty is akin to republicanism. In addition, Urbinati associates Mill's doctrine of liberty as noninterference with the harm principle. Such association should be read carefully, for it could be argued that Mill's harm principle in effect estranges him from classical republicanism. At the base of the harm principle there lies a concept unbeknownst to the ancients: the concept of individuality. ${ }^{11}$ While in classical republicanism the walls against non-arbitrariness were erected around politically constituted groups, in Mill's philosophy the protection against arbitrary interference revolves around the concept of individuality. ${ }^{12}$

This difference should not be overlooked, for if it is precisely by not restricting liberty to politically constituted groups that Mill becomes able to expand the claim for freedom qua

\footnotetext{
${ }^{11}$ On the absence of the ideal of the individuality among the ancients, see Berlin (2002, pp. 318-9).

12 It would be a gross misunderstanding to associate Mill's emphasis on individuality with atomism (pace Gairdner, 2008, pp. 11-4). As Catherine Audard (2009, pp. 86-7) points out, Mill sometimes preferred using "individuality" instead of "individual" precisely because the term individual was historically entangled with atomism. Nevertheless, Mill on occasions did use the term "individual," albeit not in an atomistic sense. Following Mill's vocabulary, this text employs "individual" and "individuality" as if they are synonyms. On the social constitution of Millian individuality, see Gustavo Hessmann Dalaqua (2018) and Katherine Smits (2004).
} 


\title{
Kalsgatos
}

Maio - Agosto

2018

Vol.15, N.2.

e-ISSN: $1984-9206$

absence of arbitrary subjection to individuals who are not organized politically and who do not even appear in the public realm (such as women of previous generations). Mill's politicizing of the private realm and demand for public interference over the relations between husband and wife would seem appalling for an ancient republican. As Mill himself acknowledges, the kind of equality he defends differs from the equality on which ancient republican thought was based. "It was thus in the free republics of antiquity [:] even in the best of these, the equals were limited to the free male citizens; slaves, women, and the unenfranchised residents were under the law of force" (CW XXI, p. 294). Since ancient republicanism identified citizenship with maleness, modern feminist republicanism inevitably signalizes a break with classical republicanism (Halldenius, 2015, p. 24 and Vega, 2008, p. 158).

Mill's feminist republicanism differs from classical republicanism because it is based on a wider concept of equality. Moreover, his doctrine of liberty is distinctively "modern" inasmuch as it pivots on the ideal of individuality. In On Liberty, Mill argues that freedom requires the absence of "harm," an obstacle that citizens encounter not only when somebody interferes with their conduct but also when the development of their potentialities is dwarfed by defective political institutions. Harm can sometimes be caused by the absence of interference. Therefore, Mill's harm principle echoes the republican tradition, for it also understands that some kinds of interference are constitutive of liberty (Urbinati, 2002, p. 165). The civil law that results from popular consent is a typical example republican thinkers invoke to illustrate this point: far from producing arbitrary subjection, the interference the civil law performs lays the ground for political liberty.

According to Urbinati (2002, p. 156), Mill's concept of freedom qua absence of arbitrary subjection brings to the fore

\begin{abstract}
the distinction between legitimate interference and arbitrary interference [and] makes it possible . . . to transform the appeal to be left alone into an appeal for emancipation. While the call for non-interference ends in a call for the indifference of the law, the call for nonsubjection culminates into a call for a just law. The former presumes a person who is essentially isolated from others, the latter a person who perceives herself as a relational being.
\end{abstract}

The greatest difference between negative liberty and republicanism is that whilst the former puts forth only a politics of power containment, the latter urges for the creation of an energetic citizenry who is always willing to monitor politicians and to fight for the abolishment of arbitrary power. The political regime that is most conducive to republican 


\section{Kalsgatos}

Maio - Agosto

2018

Vol.15, N.2.

e-ISSN: $1984-9206$

freedom, as Pettit (1997, p. 200) explains, is "a contestatory form of democracy: a democracy that . . . includes all the major voices of difference within the community, and that responds appropriately to the contestations raised against it." A contestatory democracy emphasizes "the fact that certain laws were tried and tested over a long history of challenge" (Pettit, 1997, p. 201). Laws are legitimate insofar as they "have proved capable of withstanding the contestations made against them" by the various groups comprised within the demos (Pettit, 1997, p. 201). If Pettit is right in ascribing such conception of democraticy to the republican tradition, then it seems safe to declare that Mill was indebted to republicanism, for, as chapter two of On Liberty makes clear, he thought good laws and policies could only emerge from a public and democratic debate riven with contestation.

Besides relating liberty with the absence of arbitrary subjection, another republican trait of Mill's thought lies in his connection between freedom and equality. To be sure, republican liberty "implies a condition of equality" (Spitz, 1995, p. 194). The connection between freedom and equality is a major theme of $S W$, where Mill stresses that one of his goals is to promote women's "equal freedom" (CW XXI, p. 281). According to chapter two of SW,

the true virtue of human beings is fitness to live together as equals; claiming nothing for themselves but what they as freely concede to every one else; regarding command of any kind as an exceptional necessity, and in all cases a temporary one; and preferring, whenever possible, the society of those with whom leading and following can be alternate and reciprocal (CW XXI, p. 294).

An "approach . . . to society in equality" had been made "in the free republics of antiquity" (CW XXI, p. 294). Ruling and being ruled were then reciprocal acts, and liberty was nothing but the name given to the equal share of political power. According to Mill, "the freedom of one has no solid security but in the equal freedom of the rest" (CW XIX, p. 610). As Gregory Claeys (2013, p. 171) has rightly pointed out, Mill's indebtedness to republicanism becomes obvious once one realizes Mill affirmed "the dependency of one's own liberty on maintaining that of others . . . His conception of equality, after all, aimed ultimately to supersede servitude entirely."

"In presenting the comparison between family and slavery and in defining the husband as a master and a despot, Mill revived the ... representations of oikos as an example of political tyranny in order to reinforce the value of civic government" (Urbinati, 2005 , p. 169). By portraying domestic despotism as the reverse of freedom, Mill pays 
tribute to the teachings of "Aristotle and Cicero," writers who "insisted that the tyrant, like his slaves, was alone and not free because his relations were with unfree men" (Urbinati, 2005 , p. 169). For classical republicans, freedom could be exercised only among men who treated one another as equals. Mill repurposes this republican argument in such a way as to promote gender equality and contends that, by treating women as inferior beings who were not their equals, Victorian men deprived themselves of liberty.

\section{CONCLUSION}

This article has argued that Mill can be called a feminist republican, for his commitment to gender equality and acute understanding of women's subordination to male power led him to develop a conception of freedom that evokes republicanism - which is not to say of course that Millian liberty is fully identical to, say, Aristotelian or Ciceronian liberty. Although it has significant traits with the ancient republican understanding of liberty, Mill's doctrine of freedom differs from classical republicanism insofar as "individuality" is its anchor. Whereas in classical republicanism liberty referred only to politically constituted groups, in Mill's philosophy freedom has the individual as its ultimate point of reference. It is precisely this rupture with ancient political philosophy that allows Mill to bring feminism and a republican conception of liberty together. By not restricting liberty to politically constituted groups, Mill was able to expand the claim for freedom to individuals who were not organized politically and who did not even appear in the public realm (such as women of former times).

In order to substantiate the thesis that Millian liberty steers a middle course between feminism and republicanism, four similarities between Mill's political theory and republican freedom were highlighted. For one thing, Mill's theory of liberty evokes republicanism because it identifies freedom with the absence of arbitrary interference. For both republicans and Mill, it is the absence of arbitrary subjection, not the absence of interference tout court, that indicates the presence of liberty. Ultimately, all time lived in the absence of warranties against arbitrary interference constitutes a time of non-freedom. Hence, a woman living under the dominion of a magnanimous father or husband who never interferes with her conduct remains unfree. For even if her master decides not to 


\section{Kalsgatos}

Maio - Agosto

2018

Vol.15, N.2.

e-ISSN: $1984-9206$

interfere with her actions, the fact that she has a master to begin with suffices to attest to her lack of freedom.

The second similarity is that Mill, like other republican writers, addresses the psychological torment that those living under arbitrary subjection undergo. Once they come to terms with the predicament they are in, people at the mercy of a discretionary power self-police their words and deeds in such a way as not to arouse the master's anger. The upshot of this situation is that people end up not developing their potentialities (Sallust, 1931, pp. 13-5). Thus it comes as no surprise that duplicity, sycophancy, and servility tend to be common traits among subjugated peoples. Ancient republicans would qualify these traits as effeminate; to be sure, women of previous times, as Mill poignantly describes in SW, had to act duplicitously and police themselves all the time precisely because they had to please a large number of masters: men. What is more, a significant number of them found subjection to men pleasant, for the education in which women were brought up had shaped their desires and emotions in such a way as to make them accept their slavery. For Mill, what is cruel about the subjection of women is that they are not only trained to live a life with no freedom, but also to love it. Yet even if a woman relishes her subjection and submits willingly to her master, she remains unfree. Domination reaches its apogee when those living under it cease to regard themselves unfree or when they cling to their slavery willfully.

The third similarity is that Mill also thought liberty required both the absence and the presence of something. This in turn, it has been argued, reveals that Millian liberty cannot be subsumed to the so-called "negative" concept of liberty (pace Berlin, 2000, p. 198). The absence of arbitrary subjection does not come into being spontaneously and requires the presence of instruments that allow individuals to surveil, contest and punish the conduct of those with whom they interact in power relations. The absence of interference as such does not create freedom. As Mill's discussion of the harm principle makes clear, some kinds of interference are actually constitutive of freedom (Urbinati, 2002, p. 165). Harm that is, the curtailment of freedom - is oftentimes provoked by the absence of legitimate interference. For Mill, whilst arbitrary interference inhibits freedom, legitimate interference promotes it. The civil law that results from popular consent epitomizes this point remarkably well: far from producing arbitrary subjection, the interference the civil law performs lays the ground for political liberty. The republican ideal of the Empire of the Law 


\section{Kalıgatos}

Maio - Agosto

2018

- which, as it was shown, Mill endorsed - advances freedom because it eliminates one of the main features of arbitrariness, viz. unpredictability. By regulating human affairs with a common measure that applies equally to all, the civil law bestows predictability on citizens' life.

The fourth similarity is that Mill thought freedom could only be exercised among equals. This aligns him with the republican tradition because, as Spitz (1995, p. 194) has argued, the entwinement of liberty with equality is characteristic of republicanism. Mill claimed citizens could enjoy freedom only in the presence of equals (CW XIX, p. 610). For Mill as for republicans in general, freedom requires not only the absence of arbitrary interference but also the presence of egalitarian relations which allow individuals to face one another with their heads lifted, without having to act in a duplicitous or servile manner.

\section{REFERENCES}

AUDARD, Catherine. Qu'est-ce que le libéralisme ? Éthique, politique, société. Paris: 2009.

BAIN, Alexander. John Stuart Mill: A criticism with personal recollections. London: Longmans, Green \& Co., 1882.

BARROS, Alberto Ribeiro Gonçalves. Republicanismo inglês: Uma teoria da liberdade. São Paulo: Discurso Editorial, 2015.

BERLIN, Isaiah. Two concepts of liberty. In: The proper study of mankind. New York: Farrar, Straus and Giroux, 2000.

BERLIN, Isaiah. Liberty. Oxford: Oxford University Press, 2002.

BIGNOTTO, Newton. Republicanismo. In: AVRITZER, Leonardo et al. (Orgs.) Corrupção: Ensaios e críticas. Belo Horizonte: Editora UFMG, 2008.

BURGESS-JACKSON, Keith. John Stuart Mill, radical feminist. In: MORALES, Maria (Org.). Mill's The subjection of women: Critical essays. Lanham and Oxford: Rowman \& Littlefield, 2005.

CARDOSO, Sérgio. Por que república? Notas sobre o ideário democrático e republicano. In: CARDOSO, Sérgio (Org.). Retorno ao republicanismo. Belo Horizonte: Editora UFMG, 2004.

CLAEYS, Gregory. Mill and paternalism. Cambridge: Cambridge University Press, 2013. 
COLLINI, Stefan. Introduction. In: MILL, John Stuart. The collected works of John Stuart Mill, vol. XXI. Toronto: University of Toronto Press; London: Routledge and Kegan Paul, 1984.

DAGGER, Richard. Civic virtues: Rights, citizenship, and republican liberalism. Oxford: Oxford University Press, 1997.

DALAQUA, Gustavo Hessmann. O desenvolvimento do Eu: Ética, política e justiça em John Stuart Mill. Curitiba: Editora da Universidade Federal do Paraná, 2018.

DEVIGNE, Robert. Reforming liberalism: J. S. Mill's use of ancient, religious, liberal and romantic moralities. New Haven and London: Yale University Press, 2006.

GAIRDNER, William. Poetry and the mystique of the self in John Stuart Mill. Humanitas, v. XXI, n. 1-2, 2008.

HOBBES, Thomas. Leviatã. Translated by J. P. Monteiro and M. B. N. da Silva. São Paulo: Editora Nova Cultural, 2004.

HALLDENIUS, Lena. Mary Wollstonecraft and feminist republicanism: Independence, rights and the experience of unfreedom. Oxon and New York: Routledge, 2015.

MILL, John Stuart. The collected works of John Stuart Mill, 33 vols. Toronto: University of Toronto Press; London: Routledge and Kegan Paul, 1963-1991.

MINOGUE, Kenneth. Theorising liberalism and liberalising theory. In: HAAKONSSEN, Knud (Ed.). Traditions of liberalism: Essays on John Locke, Adam Smith and John Stuart Mill. Australia: The Centre for Independent Studies, 1988.

MOOKHERJEE, Monica. Women's rights as multicultural claims: Reconfiguring gender and diversity in political philosophy. Edinburgh: Edinburgh University Press, 2009.

MORALES, Maria. Introduction. In: MORALES, Maria (Org.). Mill's The subjection of women. Lanham and Oxford: Rowman \& Littlefield, 2005.

NUSSBAUM, Martha. Mill on happiness. In: SCHULTZ, Bart; VAROUXAKIS, Georgios (Org.). Utilitarianism and Empire. Oxford: Lexington Books, 2005.

NUSSBAUM, Martha. Mill's feminism: Liberal, radical, and queer. In: VAROUXAKIS, Georgios; KELLY, Paul (Eds.). John Stuart Mill: Thought and influence: The saint of rationalism. Oxon and New York: Routledge, 2010.

PETTIT, Phillip. Republicanism: A theory of freedom and government. Oxford: Oxford University Press, 1997.

PETTIT, Phillip. Keeping republican freedom simple: On a difference with Quentin Skinner. Political theory, v. 30, n. 3, 2002.

ROSANVALLON, Pierre. La société des égaux. Paris: Seuil, 2011.

ROSEN, Frederick. Mill. Oxford: Oxford University Press, 2013. 
SALLUST. Bellum Catilinae. Translated by J. Rolfe. Cambridge, MA: Harvard University Press, 1931.

SEMMEL, Bernard. John Stuart Mill and the pursuit of virtue. New Haven and London: Yale University Press, 1984.

SIDNEY, Algernon. Discourses concerning government. Indianapolis: Liberty Fund, 1996 [1698].

SKINNER, Quentin. Liberty before liberalism. Cambridge: Cambridge University Press, 1998.

SKINNER, Quentin. A third concept of liberty. Proceedings of the British Academy, v. 117, 2002.

SMITS, Katherine. John Stuart Mill and the social construction of identity. History of political thought, v. 25, n. 2, 2004.

SPITZ, Jean-Fabien. La liberté politique : Essai de généalogie conceptuelle. Paris: PUF, 1995.

URBINATI, Nadia. Mill on democracy: From the Athenian polis to representative government. Chicago and London: The University of Chicago Press, 2002.

URBINATI, Nadia. John Stuart Mill on androgyny and ideal marriage". In: MORALES, Maria (Org.). Mill's The subjection of women: Critical essays. Lanham and Oxford: Rowman \& Littlefield, 2005.

URBINATI, Nadia. The many heads of the Hydra: J. S. Mill on despotism. In: URBINATI, Nadia; ZAKARAS, Alex (Eds.). J. S. Mill's political thought: A bicentennial reassessment. Cambridge: Cambridge University Press, 2007.

VEGA, Judith A. Feminist republicanism and the political perception of gender. In: GELDEREN, Martin van; SKINNER, Quentin (Eds.). Republicanism: A shared European heritage. Cambridge: Cambridge University Press, 2002.

WOLLSTONECRAFT, Mary. A vindication of the rights of woman. In: A vindication of the rights of woman and The wrongs of woman. New York: Pearson Longman, 2007. 
Recebido: 02/01/2018

Aprovado: $02 / 03 / 2018$ 